\title{
Ecological and Legal Regime of the Subsoil Use (by the Example of Kuzbass Coal Industry)
}

\author{
Tatyana Volkova ${ }^{1, *}$, German Pavlov ${ }^{2}$, and Inessa Schlee $^{2}$ \\ ${ }^{1}$ Kemerovo State Institute of Culture, 650056, Kемеrovo, 17, Voroshilova street, Russia. \\ ${ }^{2}$ Plekhanov Russian University of Economics, Kemerovo Institute (Branch), 650992, Kuznetsky Av. \\ 39, Kemerovo, Russia
}

\begin{abstract}
This article is devoted the problems of legal regulation of subsoil use in the coal industry as an example of legislation of the Russian Federation and the Kemerovo region. The concept of subsoil use, as well as the issues related to subsoil use in the coal industry are disclosed in the paper. The information about the valuation of subsoil plots containing reserves and mineral resources or possessing other utility is analyzed. The proposals on reforming the system of state regulation of subsoil use for the coal industry are given. These measures are aimed at ensuring effective use of subsoil and fair distribution of payments. The legal regulatory framework in this area was also analyzed by the authors.
\end{abstract}

\section{Introduction}

The purpose of this work is to consider the issue of the legal regime of subsoil use in the ecological aspect. To achieve this goal, it is necessary to consider the concept of subsoil use as a whole, as well as to study the issue that directly affects subsoil use in the coal industry.

In addition, due to the urgency of the topic, stipulated by the current ecological situation in the world and in the Kemerovo region, it is also necessary to analyze the environmental and legal regulation of subsoil use in the coal industry.

To date, in matters related to the regulation of granting rights to use the subsoil, there has been a systematic rapprochement of the permitting and contractual order of subsoil use. On the one hand, the agreement has the features of a public law order, on the other hand, the licensing conditions for subsoil use take the form of contractual relations, but only a public-law contract On the other hand, the licensing conditions for subsoil use take the form of contractual relations, but only a public-law contract. These institutions combine both public and private elements. Due to the fact that the sphere of subsoil use lies in the field of public interest, the state, being the sole owner of subsoil resources, is called upon to act in two ways: it acts as a participant in economic circulation and, at the same time, it operates as a guarantor of social interests. For this reason, the use of private-law instruments in the field of subsoil use in its pure form is not possible. This is because, since dispositive methods of regulation are not able to adequately protect the interests of society in a favorable natural environment for people, with rational subsoil use. It is also impossible to ensure environmental safety. However, the use of unilateral administrative means will also prove ineffective. Therefore, under the existing conditions, the necessity of

* Corresponding author: philosov416@kemguki.ru 
institution as a public law contract [1].

Despite the fact that in the legal and technical sense, the establishment of a legal regime for land and mineral resources thus raises a number of difficulties, from the political and economic point of view, this kind of delineation is justified. Such a model provides an opportunity for the subsoil to be left as a strategic economic resource in the state's monopoly property. At same time, it allows private ownership of land and, as a result, the formation of it as one of the objects of civil turnover exists. Among other things, the fact that land and subsoil are used for various economic purposes, it largely serves as an instrument of their delimitation from each.

All three fundamental powers pledged by the right of ownership, namely: possession, use and disposal of natural resources of the subsoil can be carried out in the majority of countries only with the consent of the state. This practice has developed as a result of the general recognition of the international rule that «the possession, use and disposition of the natural resources of one's own country, and in particular the use of subsoil and their resources, is considered as an integral element of the sovereignty of each state » [2]. Due to the fact that the land and subsoil are independent from each other from a legal point of view, it becomes necessary to determine the boundary between them, In accordance with the norms of the current legislation, the subsoil is a part of the earth's crust located below the soil layer, and if it is absent - below the earth's surface and the bottom of water bodies and streams (this provision is contained in the preamble of Law of the Russian Federation «On subsoil».

\section{Materials and methods}

To consider the issue of subsoil use in the coal industry, it is necessary to study aspects related to state regulation in this area. It is also necessary to study the problems associated with the implementation of property relations in the field of subsoil use. Thus, the methods of study and analysis are used for a more detailed consideration of the question. Also, such legal methods as the method of system-structural analysis, legal forecasting are applied. System-structural analysis in this case is necessary for consideration of the issue concerning the payment system for subsoil use. The method of legal forecasting is used in this case to study the prospects for the development of adoption of various programs in this area.

Legal regulation in the coal industry is carried out in two directions. One can emphasize regulation in both public and private law. In terms of public relations in the coal industry, such sources as international treaties of the Russian Federation, the Constitution of the Russian Federation, federal laws and subordinate regulatory legal acts are used. As for international regulation, an important document in this area is the 1993 Convention on the prevention of major industrial accidents; the Russian Federation signed the Convention on 10.02.2013. The task of all the above regulatory and legal acts is aimed at preventing and reducing the current negative impact on the environment, as well as establishing the state environmental impact assessment of coal facilities. Among federal laws, it is necessary to take into account, including the Civil code of the Russian Federation, the Tax code of the Russian Federation [16], Law of the Russian Federation of February 21, 1992, FZ- 2395-1 «On subsoil» [8], Federal Law 81-FZ of 20.06.1996 «On state regulation in the field of coal mining and use, on the specifics of social protection of employees of coal industry organizations». In addition to federal laws at the local level, regulatory acts in the field of subsoil use are also adopted. These laws were: «On the approval of the state program of the Kemerovo Region». «Ecology, subsoil use and rational water use» for $2017-2020$.

Speaking about the norms used in private law relations in the field of ecology, we can distinguish: «Order of the federal service for environmental, technological and nuclear supervision» of November 19, 2013 № 550, «Order of the Federal Service for ecological, 
deciding on the planning and execution of economic and other activities. This activity can have a negative impact on the environment [3-5]. It is worth paying attention to the fact that the overwhelming majority of norms in this area are concentrated in providing social guarantees to employees of organizations and ensuring requirements in the field of safety of hazardous facilities [6-7].

To increase the level of the Russian economy, there is an intensive increase in coal production in the regions that are coal-producing. This is necessary to meet the needs for coal products in other regions of effective exploitation of the resources of coal companies is the basis for rational subsoil use and without it; intensive development of the industry and building up the state's economic potential is impossible [8].

It should be noted that at the present stage of development of market relations the task of state regulation of subsoil use in the field of the coal industry is very actual. The urgency of this issue is due to two factors. First, there is an interest of the state in regulation that issues licenses for the right to use subsoil and expects to receive revenues to the budget in the form of taxes and payments. Secondly, there is an interest of the subsoil user himself, intending to invest in coal mining activities.

It is necessary to balance the economic interests, both state and enterprise, for rational subsoil use. This is due to the fact that the coal mining company expands its resources for the production, in turn; it uses mineral resources for the same purpose.

It is assumed that this situation shapes the interest of owners of coal-mining enterprises in increasing the environmental and economic efficiency of coal mining is reduced. On the contrary, effectiveness on the part of the state is increasing. To increase, it is necessary to take into account environmental and economic factors in the system of state regulation of coal mining. If these factors are not taken into account when regulating subsoil use in the coal industry, this can lead to both significant negative social consequences and negative economic consequences for the coal companies themselves.

When considering the issue of subsoil use in the coal industry, it is necessary to pay attention to property relations and the realization of property rights in the relations of the state as the owner of subsoil and subsoil users. The mechanism of valuation of subsoil plots plays a significant role in regulating these relations. Valuation is the revenue that an entrepreneur must receive. The revenue, in turn, is determined by the sales of the amount of minerals that can be extracted from the bowels [9]. As a rule, all objects of the state subsoil fund that take part in the state regulation of subsoil use should receive a valuation. In accordance with art. 2 of the RF Law «On subsoil» [2] such facilities include the subsoil plots in use and unused subsoil parts within the territory of the Russian Federation and its continental shelf. Nowadays, the valuation is carried out only for the sites exhibited at auctions. The purpose of this assessment is to determine the amount of the first payment that the subsoil user pays to the state for the right to extract at a certain piece of land.

Chapter 26 of the Tax Code of the Russian Federation (hereinafter referred to as the Tax code of the Russian Federation), which is called the «Mineral extraction tax» (hereinafter MET) [8] was introduced to carry out economic relations of subsoil use of the Tax code. In accordance with art. 334 of the Tax Code of the RF taxpayers are subsoil users.

The Mineral extraction tax (MET) is levied on the value of the mineral. The cost is determined by the sale price of coal. The Mineral Extraction Tax does not depend on the cost of production and losses of minerals in the interior (if not exceeded their standards). It also does not depend on the conditions of occurrence of the useful part in the subsoil and its qualitative characteristics. [10]

\section{Results and discussion}

In our opinion, the current system does not take due account of the significance of the coal field used. This importance is determined by a number of different factors. 
more productive operation of the system, some economic regulators need to be introduced as the basis for improving state regulation of subsoil use. They should be expressed in the form of payments, excises and taxes.

In Kuzbass, coal production for the first half of 2017 increased by $9 \%$ compared with the indicators of 2016 and, therefore, amounted to 139.2 million tons [7]. The coal industry has the greatest negative impact on the environment. The impact is related to methane gas emissions, active emissions of mine sewage, which lead to unconditional environmental damage. In this regard, the government of the Russian Federation approved the program for the development of the Russian coal industry for the period until 2030. The program establishes some goals and aims, as one of the goals is to increase the level of safety of coal mining enterprises, as well as to cut their harmful impact. To achieve this goal, such activities as cleaning of mine waters, as well as improving methods for forecasting negative consequences on the environment are carried out.

In turn, the program aimed to develop the coal industry also provided for the modernization of the regulatory and legal framework in the field of environmental protection. So, in 2014, Federal Law «On amending the Federal Law» On environmental protection and certain legislative acts of the Russian Federation was adopted. The main change after the adoption of this law is the provision of tax benefits and benefits for the payment for positive impact on the environment in the design and construction of environmental facilities.

The first step in the execution of the subroutine is the adoption of normative legal acts. To develop national standards in this area, the legislation of the European Union countries is observed. This is necessary for absolute compliance with the requirements of technical regulations in the field of environmental safety. In addition, they are constantly amended in order to update the requirements contained in them and consistency with the legislation of European countries. The implementation of the program promises obvious changes by 2030 on the level of developed countries in ensuring environmental safety and abandoning potentially dangerous technologies for coal mining.

In turn, the first phase of the program was held between 2013 and 2015.

As a result of this stage, the specific discharge of contaminated sewage into water bodies decreased, as well as the specific emission of pollutants into the atmosphere.

The developers of the program argue that by 2030, these indicators will have declined, and the level of waste production in external dumps will be reduced twice.

\section{Conclusion}

As a result of the analysis it was found that in the state regulation of the coal industry, which has the greatest negative impact on the environment, it is necessary to introduce certain economic regulators, expressed in the form of payments, excises and taxes for the efficiency of the functioning of the system. As a payment it is necessary to set up payment for those natural resources that are used by the enterprise; as an excise duty it is necessary to consider the collection of mining and any other types of rent in favor of society and the state; while the tax is defined as the collection of a part of the enterprise's profit for the maintenance of the state needs.

With this payment system this criterion can be considered as the ecological efficiency of subsoil use. This efficiency consists of the net income of the enterprise with the deduction of all tax exemptions.

Normative is legal act, adopted in this field for preventing and reducing the negative impact on the environment, also need changes and additions. At present it is necessary to adopt norms aimed at ensuring environmental and conservation activities in the field of subsoil use in the coal industry. The government of the Russian Federation has approved a program for the development of the Russian coal industry for the period up to 2030 at the 
of the Administration Board of the Kemerovo region at the local level. This resolution is aimed at rational use of mineral resources for the period 2017-2020. It is important to improve the mechanisms of environmental and legal regulation on the basis of a systematic approach. This approach should guarantee functional interaction of norms of energy, environmental and other branches of legislation, their balanced correlation and interconnection.

\section{References}

1. M. Shmojo, Direction of high efficiency of coal fueled power generation in Japan. Lecture in the Summer School of UNESCO in Moscow (Clean Coal Technologies, Moscow, 1996)

2. Law of the Russian Federation of 21.02.1992 № 2395 "On subsoil" (Law Office, Moscow, 1996)

3. S. Anyona, B.K. Rop, Economics and Innovation Management, 1, 17-29 (2017) DOI: 10.26730/2587-5574-2017-1-17-29

4. N. N. Golofastova, V. G. Mikhailov, I. V., Seredyuk I.V. Economics and Innovation Management, 1, 66-75 (2017) DOI: 10.26730/2587-5574-2017-1-66-75

5. J. Janočko, M. Cehlár, Z. Šimková, Economics and Innovation Management, 3, 32-45 (2017) DOI: 10.26730/2587-5574-2017-3-32-45

6. N. N. Golofastova, V. G. Mikhailov, I. V., Seredyuk I.V. Economics and Innovation Management, 1, 66-75 (2017) DOI: 10.26730/2587-5574-2017-1-66-75

7. V. G. Mikhailov, Ya. S. Mikhailova, Economics and Innovation Management, 3, 73-79 (2017) DOI: 10.26730/2587-5574-2017-3-73-79

8. Y. A. Vyskubenko, Comprehensive Report to Congress "Clean Coal Technology Program. Completing the Mission" (The US Department of Energy, Whashington, 1994)

9. B. D. Klukin, Mining relations in the countries of Western Europe and America England, Canada, the USA, France, Germany (Gorodets, Moscow, 2000)

10. W. Renzenbrink, K. Rudolf, Baunkohle, 10, 88-97 (1991) 